Vol. XXVII No $1 \quad 2021$

\title{
THE IMPORTANCE OF LEADERSHIP DEVELOPMENT AND SELF-DEVELOPMENT WITHIN THE ORGANIZATION
}

\author{
Mihai Adrian ZISU \\ “Nicolae Bălcescu” Land Forces Academy, Sibiu, Romania \\ adrianzisu1967@gmail.com
}

\begin{abstract}
Leadership being a process of social influence, it is imperative to train true leaders, emotionally intelligent, able to motivate and mobilize people in the organizations they lead, in order to achieve beneficial results for all parties involved: organizations, leaders, disciples. Within the military organization, the military leader must fulfill his mission in theaters of operations, not in the context of the "the end justifies the means", not by minimizing the human component " stepping over bodies", but by exercising effective servant leadership from a multicultural perspective. The leader-subordinate relationship is reciprocal and influences both the performance of the individual and the organizational one. Leadership can be based on a personality trait or can be seen as a behavioral category, being related to motivation, interpersonal behavior and the communication process. Good leadership involves the actual process of delegation, but not before leaders form and train other leaders, as real leadership is exercised "face to face" and trough interaction. The fundamental premise from which we start our approach is that the leader matters, that the people at the top of the hierarchy certainly influence the efficiency of any organization. By setting standards, goals and priorities a leader can bring about changes in daily performance. It can permanently influence the meaning of the evolution of the organization by establishing a strategic vision and formulating longterm objectives.
\end{abstract}

Keywords: self-development, leader, organization

"The secret of success is hidden in our daily agenda. If you constantly invest in the development of management science, letting the knowledge multiply, the inevitable result is a harmonious development over time"[1].

\section{Introduction regarding leaders' personality}

The proper functioning of the organization depends on the effectiveness of leaders and the combination of leadership and management skills, and using them for mutual balance. It is said that no one is both a good leader and a good manager. Leaders have innate abilities, which are ennobled through education, each having an untapped leadership potential, as each of us has a physical potential that we do not use to its full value. Therefore, the configuration of warm-up training acquires a special importance. In a world that's in continuous transformation, which is constantly evolving, organizations are increasingly important in the life of each individual. Given the fact that most of the time people spend in organizations, they become the place of all accomplishments, where they feel happy, but also unhappy, they feel good, satisfied, but also sad, dissatisfied. In organizations, man 
builds or loses his self-identity, his interiority is affected or he shapes it according to his own will. Inevitably, organizations influence people, but people can also influence organizations. As leadership is a process of social influence, it is imperative to form true leaders, emotionally intelligent, able to motivate and mobilize people in the organizations they lead, in order to obtain beneficial results for all parties involved: organizations, leaders, disciples.

\section{Relation between motivation and character in leadership}

Mahatma Ghandi, the reformer of Indian origin, said: ,, The difference between what we do and what we are able to do would be enough to solve most of the world's problems" [2]. That's how big our potential is.

Remaining in leadership positions formal leaders who do not adapt to new modern trends in the evolution of organizations or do not understand the complexity of the battlefield, if we refer to the military organization, beyond any state-of-the-art technological endowment of the army, we take risks through the attitude of people, because of their incompetence or convenience, to give up the achievement of great goals, to reach high standards, practically, ,we get to be content with a little" [3].

„The development of the concept of leadership is directly proportional to the manifestation of the relationship between the leader and the structure on which he exercises his command act. This report explains very well the success of a leader, given his personal skills, but also the efficiency of his actions in a much broader, social plan" [4]. In order to be prepared at any time to overcome obstacles in his activity, the leader needs a continuous development both individually and socially, as well as professionally. Leaders who give up such continuous development are threatened by failure in leadership. The personal and professional development of the leader must face the challenges confronted by the organization to which he belongs.
„The problems of organizations are becomming more and more complex. There are too many ironies, polarizations, dichotomies, dualities, ambivalences, paradoxes, confusions, contradictions, opposites and misleads that any organization faces and must understand" [5].

Regardless of the nature of the organization, the leadership process is essential for its development. Leadership is focused on the future and is meant to make it better than the present.

„Leadership is present in any human activity, as a dynamic process of organization and coordination by a group, in a certain period of time and in a specific organizational context, of other groups of members of the organization, in order to perform specific tasks" [6].

True leaders are formed through learning and education, they are not born. In each of us there is a potential leader that we have not exploited for various reasons, more or less plausible.

"In the past, it was thought that you were born with the skills of a leader. Leaders were born, not made, attracted by their calling through an impenetrable process. It could be called the theory of the Great Man in the field of leadership. It implies that the power is being invested in a very limited number of people who became leaders through inheritance and destiny. The ones with blue blood could rule; everyone else had to be led. You were either born with it or without it. Neither teaching nor desire could change your fate" [7].

To be a successful leader you must go through a continuous learning process. Your genetic background is not enough to become an effective leader.

„Personal success without having a leadership talent brings with it only minimal efficiency. A person's impact depends very much on his leadership skills. The more you want to climb higher, the more you need this talent. The stronger you want the impact, the greater your influence" [8]. 
Studies on self-development have identified in its dynamics several phases:

- setting the goals of the activity,

- observing one's own activity,

- recording the results of the activity,

- evaluation of results,

- strengthening, fixing, using the results if they are appreciated as successful.

The stages of leadership development are:

1. I am not aware of what I do not know (as long as a person does not realize that he lacks knowledge, skills, etc., he can not develop or improve);

2. I am aware of what I know (when we reach a leadership position in a favorable situation, but no one around us follows us, it is the moment when we must understand that it is imperative to learn leadership);

3. It becomes clear that I am improving and assimilating knowledge (it happens when you start to develop your leadership talent and those around you are amazed by your performance);

4. I follow my path because I can (following the efficiency obtained in the third stage, in this moment leadership becomes an automatic process).

The fundamental idea is that the leader must have the professional and moral competence to lead people, as well as to contribute to their development. The mission of leaders is to inspire the organization, to excite people in achieving their goals, to make them proud of their membership in the group and to support them in obtaining job satisfaction. Leaders are those who must create a climate of family work, conducive to the development of positive, creative emotions, with a constructive impact on achieving the organizational goal.

„During a visit to North Africa during World War II, Churchill asked Auchinleck (British Marshal defeated by Rommel at El Alamein. Supreme Commander of the Armed Forces in India and Pakistan during the independence of these countries) who does not leave the office and does not review his troops, explaining their plans. Familiarity breeds contempt, the general replied.
Churchill chuckled, "I don't think anything can be born without familiarity!" [9]

Unlike managers, leaders will make people share in their vision and will highlight the important role of each individual in achieving organizational goals.

"The fact of knowing how to set ambitious goals is an integral part of the dynamics of a leader, as opposed to that of a manager. The more reasonable manager sets equally reasonable goals, in accordance with the means available, possibly keeping even a small margin of safety, in order to be completely sure that he will achieve the expected results.

In other words, a manager sets goals based on the means acquired, while a leader or a visionary mobilizes himself and his entourage in finding or developing the means by which he will see his ambition realized" [10]

In order to be aware of the level of the people in the organization and to know to what extent you can rely on them to achieve a positive organizational change or to set ambitious goals to be achieved, high standards must be set at the organizational level.

"Set goals that are hard to achieve," Welch recommends. ,If you don't do this, you will never know how many of your employees can actually do it" [11].

Successful achievement of goals, especially in crisis situations, is only possible when the leader is followed by all disciples who are strongly, emotionally involved in achieving the expected results.

„I have found that by doing what seems impossible, in reality, we often achieve the impossible; even when we do not achieve the impossible, we inevitably end up doing more than we set out to do.

Achieving and exceeding goals", according to Welch, ,avoids the mediocrity that can arise from compromise" [12].

It will be much easier for you to differentiate between subordinates after exposing them to such a challenge related to difficult-to-achieve goals. You will also appreciate them much more correctly in 
terms of professional competence. At the same time, people must be constantly encouraged for their efforts to gain selfconfidence and mobilized to move forward.

„Take a look at this comparison between what happens when people feel victory over what they feel when they expect to be defeated:

\section{When people feel victory:}

- They sacrifice themself to succeed

- They always look for ways to win

- They're getting energetic

- They follow the game plan

- They're looking for their teammates

When people feel defeat:

- They do their worst

- They look for excuses

- They're getting easily tired

- They abandon the game plan

- They hurts others

To help people believe they can win, put them in a position to try small successes. Encourage them to fulfill or take on responsibilities that you know they can accomplish and do well. Give them the support they need to succeed. As the Greek orator Demosthenes said: Small opportunities are always the beginning of great achievements. Over time, as their confidence grows, they will face more and more difficult challenges, but they will be able to face them with confidence and competence because of the positive record of the problems they have solved. "[13].

Ronald Osborn remarks: ,If you don't try to do something beyond what you've already managed to do, you'll never grow" [14].

Priorities need to be set in order to achieve efficiency. We cannot pay special attention to small things, for the accomplishment of which we need to waste our energy and time. To maintain priorities you must:

- we check (periodically we will evaluate the ratio between effort, effectiveness, reward);

- we delegate (we will identify the activities that, in terms of importance and degree of difficulty, can be taken over by disciples in order to achieve them);
- we approximate (we identify the projects of special importance, for us and the organization, and we frame them in time, regarding the way of their realization).

In order to achieve a remarkable success at organizational level, it is necessary to eliminate the restrictions as follows:

- elimination of obstacles between functions;

- elimination of obstacles in the pyramid hierarchy;

- elimination of communication barriers between different departments and employees or between employees and external factors;

- interaction with important people.

The success or failure of the leader is determined, first of all, by the situation in which he acts. A well known truth that it is often ignored, shows us that success in leadership is achieved by that leader who relies on the collective, on the experience and participation of people, on the capacity and initiative of subordinates. It is important that we are genuinely interested in the needs, turmoil, and needs of the people, not only because it is democratic to do so, but also because it benefits the work. The leader must know how to listen, to be able to make subordinates feel their importance in the organization in which they operate.

„The evolution in terms of managerial power goes through several stages, such as the need to develop interpersonal skills, underused and therefore underdeveloped, to better understand them, to motivate, convince, inspire, guide or determine them to evolve on collaborators" [15].

In the face of the various challenges posed by life in general, we can acquire certain skills necessary to use intelligent behavior.

„, To be successful and accomplished today, you must learn to develop these skills to the fullest, because those who use a unique combination of reason and feeling are the ones who get the best results" [16].

Starting from the premise that in order to lead others you must learn to lead yourself, the leader has the obligation to be a worthy 
example to follow, capable of organizational transformations, character modeling and elimination of preconceived mentalities.

„Guidance means pouring your life on other people and helping them reach their potential. The power of the coach or mentor is so great that he can see with his own eyes how the lives of those he influences change. By offering yourself, helping others to overcome obstacles in life and showing them how to evolve personally and professionally, you will help them reach a new standard of living. You can really make a difference in their lives" [17].

Of course, not all leaders want to grow. Because they behaved as leaders until they achieved a top position in the organization and indulge in the situation of not wanting change, even if it has beneficial effects for the organization.

„Leaders who treat change as an enemy will fail in their actions" [18].

Another beneficial perspective in the development of the leader and the people, implicitly, is the perspective of coaching and mentoring.

„The role of coach and mentor are very similar. The only real difference is that a coach focuses on developing a person's skills in concrete tasks, while the mentor has a broader perspective. Usually, the mentor has a long-term relationship with the person in question, he is a kind of counselor for a wider range of problems, at any time" [19].

The involvement of leaders in people's development must not deprive them of the creativity, imagination and responsibility needed to solve the problems they face with their personal touch, as well as the tasks they receive.

„A leader must make it easier to solve the problem, but he must let his subordinates solve most of the problems. By solving the problem as a last resort, the leader can help the organization grow and prosper. General George Paton advised: Never tell subordinates how to do it. Tell them what to do and you will be amazed at their ingenuity" [20].

Warren Bennis and Burt Nanus made a discovery about the relationship between the development and the science of leadership: „A person's ability to develop and hone talents is what differentiates leaders from those who follow them" [21].

Not all leaders develop the same way, but regardless of the level of development or the pace of evolution, rigorous training is needed to become effective.

"While it is true that some people are born more gifted than others, the ability to lead is actually an accumulation of talents, most of which can be learned or perfected. But this process does not take place overnight. Leadership science is complicated. It has many facets: respect, experience, emotional power, talent, discipline, vision, momentum, timing - and the list goes on. As you can see, many factors related to the science of leadership are intangible. That's why leaders need so much training to be effective" [22].

I conclude by saying that leaders must develop and self-develop, both for themselves and for the people who follow them, in order to achieve collective good and organizational success.

„Writer Mark Twain warned: Beware of people trying to minimize your ambitions. Small people always do this, while really big ones make you feel like you can grow up" [23].

\section{Conclusion}

To understand complex, volatile, and probabilistic environments, to build a plan or vision for the future, leaders need to have skill sets. Failure to achieve this vision will result in defeat.

It is also important to remember that only in the conditions in which man knows himself in an objective way and on the basis of scientific methods, he can establish the fields in which he considers himself competent or not, the qualities that he overestimates or underestimates, the rules according to which he thinks it is 
appropriate to behave, and the aspirations and needs to which he gives priority.

The concept of self-development means self-management of one's own adaptive resources, control over one's own behaviour, involvement of the individual in the basic steps of a behaviour modification program, being promoted by one of the latest applications of the behaviourist perspective on learning, namely cognitive behavioural change.

\section{References List}

[1] John C. Maxwell, Cele 21 de legi ale liderului, Editura Amaltea, București, 2002, p. 35.

[2] John Maxwell, Lider la 360 , Editura Amaltea, București, 2009, p. 175.

[3] http://www.citatepedia.ro/index.php?id=163279, accesat la data de 07.06.2021.

[4] Dan Ghica Radu, Constantin Grigoraș, Elena Florișteanu, Dimensiuni calitative ale curriculum-ului pentru formarea ofițerilor, Editura Academiei Forțelor Terestre „, Nicolae Bălcescu”, Sibiu, 2010, p.129.

[5] Warren Bennis, Burt Nanus, Liderii: strategii pentru preluare a conducerii, Editura BUSINESS TECH INTERNATIONAL PRESS, București, 2000, pp. 19-20.

[6] Constantin Apetroaie, Conducerea forțelor în acțiunile militare multinaționale, Editura Centrului Tehnic-Editorial al Armatei, București, 2008, p. 47.

[7] Warren Bennis, Burt Nanus, Liderii: strategii pentru preluare a conducerii, Editura BUSINESS TECH INTERNATIONAL PRESS, București, 2000, p. 17.

[8] John Adair, Peter Reed, NU BOSS CI LIDER, Editura Meteor Press, București, 2004, p.167.

[9] John Adair, Peter Reed, NU BOSS CI LIDER, Editura Meteor Press, București, 2004, p.167.

[10] Alain Cardon, Cum poți deveni COACH, Editura Codecs, București, 2008, p. 135.

[11] Robert Slater, 29 DE SECRETE ALE LEADERSHIPULUI DE LA JACK WELCH, Editura ALL, București, 2009, p. 118.

[12] Robert Slater, 29 DE SECRETE ALE LEADERSHIPULUI DE LA JACK WELCH, Editura ALL, București, 2009, p. 118.

[13] John C. Maxwell, Jim Dornan, Cum să devii o personă cu influență, Editura Amaltea, București, 2002, p. 81.

[14] John C. Maxwell, Jim Dornan, Cum să devii o personă cu influență, Editura Amaltea, București, 2002, p. 143.

[15] Patrick Amar, 50 de experimente privind psihologia managerului: cum să reușești la locul de muncă, Editura Polirom, Iași, 2009, p. 146.

[16] Travis Bradberry, Jean Greaves, Inteligența Emoțională, Editura Amaltea, București, 2008, p.31.

[17] John C. Maxwell, Jim Dornan, Cum să devii o personă cu influență, Editura Amaltea, București, 2002, p. 12.

[18] Robert Slater, 29 DE SECRETE ALE LEADERSHIPULUI DE LA JACK WELCH, editura ALL, București, 2009, p. 18.

[19] Max Landsberg, Coaching, Editura Curtea Veche, București, 2005, p. 106.

[20] Perry M. Smith, Preluarea comenzii - un ghid practic pentru lideri, Editura Militară, București, 1999, pp. 22-23.

[21] John C. Maxwell, Cele 21 de legi ale liderului, Editura Amaltea, București, 2002, p. 36.

[22] John C. Maxwell, Cele 21 de legi ale liderului, Editura Amaltea, București, 2002, p. 36.

[23] John C. Maxwell, Jim Dornan, Cum să devii o personă cu influență, Editura Amaltea, București, 2002, p. 63. 